\title{
Czesi i Słowacy na drodze do niepodległego państwa (1914-1918)
}

Słowa kluczowe: pierwsza wojna światowa, Czechy, Słowacja, niepodległość

Keywords: World War I., Czech Republic, Slovakia, independence

\begin{abstract}
The following article describes the struggle of Czechs and Slovaks for independent Czechoslovakia during World War I and explains why Austria-Hungary could not survive.
\end{abstract}

\section{Ziemie czeskie na początku pierwszej wojny światowej}

Do wybuchu Wielkiej Wojny polityków czeskich pragnących pełnej niepodległości było niewielu. Polityka czeska nie dążyła do całkowicie niepodległego państwa w sensie oddzielenia się od monarchii Habsburgów. Idea niepodległego państwa wydawała się wielu Czechom nie do zrealizowania zaś Austria, mimo wszelkich niedostatków, była postrzegana jako naturalna przestrzeń dla czeskiego rozwoju narodowego. Biorąc pod uwagę, że takie państwo zamieszkiwałoby ponad trzy miliony Niemców i graniczyłoby praktycznie tylko z Niemcami, zdaniem wielu nie byłoby w stanie się utrzymać. Ideałem polityki czeskiej było więc osiągnięcie takiego statusu, jaki od 1867 r. posiadały w ramach monarchii Węgry: zamiast dualizmu Austro-Węgierskiego powstałby trializm Austro-Czesko-Węgierski. Celem artykułu jest pokazanie, w jaki sposób ta sytuacja stopniowo się zmieniała i jak w końcu - w opinii polityków czeskich - zwy-

1 Prezentowany tekst stanowi rozdział książki: J. Rychlík, W. Penczew, Historia Czech, ATUT - Polsko-Czeskie Towarzystwo Naukowe, Wrocław, która ukaże się w 2020 r. 
ciężyła opcja Tomáš G. Masaryka i Edvarda Beneša opowiadająca się już od 1914 r. za połączeniem Czech ze Słowacją i powstaniem całkowicie niezależnego od Austro-Węgier państwa czesko-słowackiego. Ostatecznie Czechosłowacja stała się takim samym państwem wielonarodowym, jakim były Austro-Węgry. Tekst w ten sposób uzupełnia naszą wiedzę na temat problemu upadku państw wielonarodowych i powstawania „narodowych” w $1918 \mathrm{r}^{2}$

Wybuch wojny 28 VII 1914 r. wpłynąl na wewnętrzną politykę Austrii. Już 25 VII 1914 r. zamknięto Radę Państwa, której budynek przekształcono wkrótce w szpital wojskowy i rozwiązano wszystkie sejmy krajowe. W całej monarchii wprowadzono stan wyjątkowy, zawieszając niektóre prawa obywatelskie. Zaostrzono cenzurę pra$\mathrm{sy}^{3}$, wprowadzono kontrolę korespondencji i rozmów telefonicznych, ograniczono wyjazdy obywateli za granicę. Podejrzane osoby mogły zostać bez wyroku sądu umieszczone na nieograniczony czas w specjalnych obozach internowania ${ }^{4}$.

Cesarz jako zwierzchnik armii powierzył naczelne dowództwo swemu krewnemu z bocznej linii Habsburgów arcyksięciu Fryderykowi (1856-1936), posiadaczowi rozległych dóbr na Śląsku Cieszyńskim, chociaż w rzeczywistości spoczywało ono w rękach szefa sztabu generalnego hrabiego Franza Conrada von Hötzendorfa (1852-1926). Sztab generalny przejął faktyczną władzę w państwie, a armia zaczęła odgrywać w nim decydującą rolę. Wojsku podporządkowano wszystkie instytucje administracji, także cesarscy namiestnicy musieli działać w zgodzie z miejscowym

2 Na temat powstania Czechosłowacji patrz: J. Rychlík, 1918 - Rozpad Rakouska-Uherska a vznik Československa, Praha 2018, J. Galandauer, Karel I., poslední český král, Praha-Litomyšl, 2004; A. Klimek, Ǩ́jen 1918. Vznik Československa, Praha 1998; J. Galandauer, Vznik Československé republiky 1918. Programy, projekty, préedpoklady, Praha 1988; M. Hronský, Boj o Slovensko a Trianon 1918-1920, Bratislava 1998; M. Hronský, M. Pelník, Martinská deklarácia. Cesta slovenskej politiky k vzniku Česko-Slovenska, Bratislava 2008; F. Čada, 28. ř́jen 1918. Skutečnost, sny a iluze, Praha 1988; M. Hronský, Slovensko pri zrode Československa. Bratislava 1987.

$3 \mathrm{Z}$ formalnego punktu widzenia aż do tego momentu w Austro-Węgrzech cenzura nie istniała. Każdy mógł pisać co chcial, jednak rozpowszechnianie druku było możliwe jedynie w przypadku, gdy tekst nie naruszał prawa. Aby uniknąć strat spowodowanych zakazem rozpowszechniania gotowych już dzieł wydawcy, dyrekcje teatrów czy producenci filmowi przedkładali wcześniej teksty urzędnikom, co w rzeczywistości oznaczało istnienie cenzury prewencyjnej. W przypadku stwierdzenia naruszenia prawa cenzor podkreślał stosowny fragment tekstu i odnotowywał przepis, który został złamany. Przeciwko decyzji cenzora można było odwołać się do sądu. W ocenzurowanym druku pozostawiano puste miejsce, by czytelnik mógł zorientować się, że dokonano ingerencji. Taką procedurę przejęto w Czechosłowacji w latach 1918-1938.

4 F. Soukup, 28. ř́jen 1918. Předpoklady a vývoj našeho odboje domácího v českoslovesnké revoluci za státní samostatnost národa. I. díl. Praha 1928, s. 105-114. 
dowództwem. Ludność cywilna podlegała rozkazom pełnomocników wojskowych, którzy mogli w razie potrzeby przymusić ją do wykonywania obowiązków na rzecz wojska, przedłużać czas pracy czy ograniczać wysokość płac. Zgodnie z prawem armia miała prawo rekwizycji majątku, jeśli nie był on konieczny do utrzymania, zabierano więc zapasy jedzenia, wozy, metale szlachetne itp. ${ }^{5} \mathrm{Na}$ Węgrzech, gdzie konstytucja nie pozwalała na powrót do żadnej formy rządów absolutystycznych, parlament zbierał się nadal, a instytucji rządowych nie podporządkowano armii. Jednak i tu dowódcy wojskowi mieli bardzo szerokie kompetencje ${ }^{6}$.

Działania wojenne ominęły ziemie czeskie, jednak ich udział w wojnie był znaczący, zwłaszcza pod względem zasobów ludzkich. Do armii i sił samoobrony (Landwehr) wcielono stopniowo wszystkich mężczyzn zdolnych do służby wojskowej $\mathrm{w}$ wieku od 18 do 50 lat. Ubytek siły roboczej był tak znaczący, że w wielu miejscach, po raz pierwszy w historii, mężczyzn musiały zastąpić kobiety powoływane do pracy w urzędach, fabrykach, kolei czy transporcie publicznym. Od 1915 r. gospodarkę w Austro-Węgrzech przestawiono na potrzeby wojska. Rolnicy mogli zachować jedynie plony potrzebne na własny użytek, resztę musieli odsprzedać państwu po urzędowych cenach. Ustalono minimalne i maksymalne płace w przemyśle, w wielu gałęziach gospodarki robotników zmobilizowano, zakazując im opuszczania miejsca zamieszkania bez specjalnego zezwolenia. W tym samym roku zaczęto wprowadzać reglamentację towarów, najpierw żywności, a później innych produktów przemysłowych. System ten nie działał jednak tak sprawnie jak w sąsiednich Niemczech, głównie z uwagi na wszechobecną korupcję. Wojna pociągnęła za sobą olbrzymią inflację. Chłopi nie chcieli sprzedawać żywności za pieniądze, żądając w zamian złota czy innych cennych przedmiotów. W czasie pierwszej wojny światowej w wiejskich chałupach pojawiły się pianina, luksusowe meble, drogie ubrania czy biżuteria, a wielu rolników znacznie się wówczas wzbogaciło. W miastach zaczęły wybuchać strajki i protesty głodowe ${ }^{7}$.

Czesi nie wiązali z wybuchem pierwszej wojny większych nadziei, a ich sympatie stały wyraźnie po stronie przeciwników Austrii, zwłaszcza Serbii, prowadzącej sprawiedliwą wojnę, i Rosji (najmniejsze wsparcie okazywano Włochom). Już w czasie mobilizacji wielu rezerwistów okazywało przyjazną postawę wobec Serbów i Rosjan. Nie znaczy to jednak, by większość Czechów świadomie opowiadało się przeciwko

5 J. Rychlík, 1918 - Rozpad Rakouska-Uherska, s. 73.

6 P. Kónya et. al., Dejiny Uhorska (1000-1918), Prešov 2013, s. 739-741.

7 J. Rychlík, 1918 - Rozpad Rakouska-Uherska, s. 72-75. 
wojnie. Jeśli spojrzymy na czeskich żołnierzy jako całość, dostrzeżemy, że wypełniali oni swoje obowiązki wobec armii, czy to jako prości rekruci, czy jako oficerowie i podoficerowie rezerwy. W korpusie oficerskim Austro-Węgier Czesi stanowili około 11-12\% (w korpusie oficerów zawodowych jednak tylko 5\%), choć procent czeskich lekarzy wojskowych i kapelanów był w porównaniu z innymi narodami monarchii najwyższy ${ }^{8}$. Wielu czeskich oficerów zawodowych z powodzeniem pełniło wysokie funkcje dowódcze. Tylko niewielka część żołnierzy czeskich zdecydowała się na dezercję lub dobrowolne poddanie się nieprzyjacielowi. Od początku $1915 \mathrm{r}$. liczba przypadków dezercji zaczęła się co prawda wojny, trudno jednak mówić o jakimś masowym zjawisku. Wielu Czechów uważało Austro-Węgry za swoją ojczyznę, a służbę wojskową traktowało jako obywatelski obowiązek ${ }^{9}$.

Czeska scena polityczna wydawała się zaskoczona wybuchem wojny, a jej najważniejsze siły nie bardzo wiedziały, jak na nią zareagować. Zresztą zamknięcie Rady Państwa i sejmów krajowych ograniczyło możliwość działalności politycznej. Przed wojną jedynie Radykalna Partia Państwowoprawna postulowała pełną samodzielność ziem czeskich, miała jednak marginalną pozycję. W pewien sposób idea niepodległości bliska była także narodowym socjalistom, których przywódca Václav Klofáč (1868-1942) został internowany 4 IX 1914 r. (na wolność wyszedł dopiero 12 VII 1917 r. $)^{10}$. Najważniejsze partie polityczne, Młodoczesi, agraryści i socjaldemokraci, zachowywały lojalność wobec Austrii. Czeska Partia Socjaldemokratyczna (ČSSD) jeszcze na swym ostatnim przedwojennym zjeździe w $1913 \mathrm{r}$. jednoznacznie opowiedziała się za pozostaniem Czech w granicach monarchii. Większość polityków zadeklarowało poparcie dla wojennych wysiłków Austro-Węgier licząc, że Czesi otrzymają w zamian szansę realizacji swych narodowych postulatów. Jesienią 1915 r. rozpoczęly się rozmowy na temat stworzenia jednolitego stronnictwa narodowego, które reprezentowałoby wspólne stanowisko Czechów w przypadku zmian w organizacji monarchii. Rozmowy nie przyniosły jednak zbliżenia stanowisk i zakończyły się po kilku miesiącach ${ }^{11}$. Z kolei Słowacy przybrali bierną pozycję. Już 5 VIII 1914 r. Słowacka Partia Narodowa ogłosiła, że na czas wojny zawiesza

8 K. Pichlík, B. Klípa, J. Zabloudilová, Českoslovenští legionárí 1914-1920, Praha 1996, s. 11.

9 I. Šedivý, Češi, české země a Velká válka 1914-1918, 2. vyd. Praha 2014, s. 144-150; J. Fučík, Osmadvacátníci. Spor o českého vojáka I. světové války, Praha 2006, s. 117-119.

10 F. Soukup, 28. ř́jen, s. 153-156.

11 J. Křen, Konfliktní společenství. Češi a Němci 1780-1918, Praha 1990, s. 419-420. 
jakiekolwiek działania polityczne ${ }^{12}$, a w ślad za nią poszły wkrótce i inne ugrupowania, w tym socjaldemokraci, którzy tworzyli autonomiczną organizację w ramach węgierskiej partii socjaldemokratycznej ${ }^{13}$.

W istniejących okolicznościach polityka aktywizmu, a więc uczestniczenia w austriackim życiu politycznym, nie dawała zbyt wiele nadziei na sukces, bowiem $\mathrm{w}$ trwających konflikcie narodowościowym wojna przechyliła szalę wyraźnie na stronę Niemców. Zarówno arcyksiążę Fryderyk jak i Conrad von Hötzendorf byli zwolennikami „niemieckiej Austrii”, a toczącą się wojnę postrzegali jako walkę żywiołu niemieckiego ze słowiańskim. Już w październiku 1914 r. zaczął powstawać program „niemieckiej przebudowy Austrii”, który zyskał konkretniejszą formę na wiosnę 1915 r. (stąd nazywany był „programem wielkanocnym” - „Osterbegehrschrift”), a ostateczną formę na wiosnę 1916 r. Galicja, Bukowina i Dalmacja miały zostać odłączone od Przedlitawi i zyskać własny statut, przy czym miano zagwarantować prawa tamtejszym Niemcom. Pozostałe ziemie, w tym Czechy (także Istria z uwagi na dostęp do morza), miały zostać połączone w jedną całość, „zachodnią Austrię", mającą wyraźnie niemiecki charakter ${ }^{14}$. Czesi i Słoweńcy staliby się w nim mniejszością narodową, język niemiecki byłby językiem urzędowym, którym powinien władać każdy obywatel, a na terenach niemieckojęzycznych mogłyby istnieć tylko niemieckie szkoły. Prawu narodów niegermańskich na tych obszarach poświęcono w programie „Osterbegehrschrift” jedno zdanie, w którym stwierdzano, że „pod uwagę mają być wzięte praktyczne potrzeby obcojęzycznych społeczności w urzędach i szkołach" ${ }^{15}$. Z ziem słowiańskich większą uwagę poświęcono jedynie Czechom, które planowano podzielić na czysto niemieckie pogranicze oraz terytoria mieszane narodowościowo z czeskim jako drugim, pobocznym językiem urzędowym $^{16}$.

W listopadzie 1916 r. Wilhelm II i Franciszek Józef I wydali w imieniu swoich państw proklamację zapowiadającą utworzenie państwa polskiego na terenie dawnej Kongresówki i Galicji (tzw. Akt 5 listopada). I chociaż w Berlinie i Wiedniu nie było

\footnotetext{
12 „Národnie Noviny“, 6 VI 1914, s. 1. Patrz też: Dokumenty slovenskej národnej identity a štátnosti (DSNIŠ), I. Bratislava 1998, dok. 134, s. 431-433.

13 Słowacka Partia Socjaldemokratyczna odłączyła się w 1905 r. od węgierskich socjaldemokratów, jednak samodzielnie istniała tylko przez rok. W 1906 r. ponownie dołączyła do struktur węgierskich, zachowując jednak autonomię.

14 J. Křen, Konfliktní společenství, s. 405-406.

15 Tamże, s. 403.

16 J. Galandauer, Vznik Československé republiky, s. 18.
} 
zgody co do kształtu państwa polskiego oraz sposobu przyłączenia do niego Galicji, z punktu widzenia Niemców nie miało to większego znaczenia: Galicja i tak miała zostać odłączona od Przedlitawi, a ludność niemiecka zyskałaby w niej pożądaną przewagę liczebną. Wkrótce doszło do zmiany na fotelu premiera Austrii, która tylko wzmocniła program wielkoniemiecki. Hrabia Karl Stürghk, konserwatywny austriacki arystokrata, nie był zwolennikiem „niemieckiej Austrii”, bojąc się otwartego buntu narodów słowiańskich, jednak 21 X 1916 r. padł ofiarą zamachu ${ }^{17}$. Po przejściowym rządzie Ernesta von Koerbera, 20 grudnia cesarz mianował premierem hrabiego Heinricha Clam-Martinica (1863-1932), który był co prawda potomkiem starej czeskiej arystokracji, jednak w odróżnieniu od swego ojca i stryja nie popierał czeskich postulatów narodowościowych.

Czeskie partie polityczne były bez wyjątku zaniepokojone przygotowanymi planami przekształcenia Przedlitawi. Chociaż nie udało się zrealizować pomysłu organizacji wspólnego stronnictwa narodowego, w obliczu niemieckiego zagrożenia powołano 19 XI 1916 r. Czeski Związek Posłów Rady Państwa (Český svaz poslanců na rríšské radě), a równocześnie ponadpartyjny Komitet Narodowy (Národní výbor), mający koordynować działalność środowisk politycznych ${ }^{18}$. Oznaczało to początek końca polityki aktywizmu. I tak, paradoksalnie, niemiecki program narodowy tchnął energię w czeską walkę o niepodległość.

\section{Ruch antyaustriacki za granicą}

Jak już wspomniano u progu pierwszej wojny światowej żadna z liczących się sił politycznych w Czechach, pomijając marginalną Radykalną Partię Państwowoprawną, nie wysuwała postulatu niepodległości Czech. Niemniej wśród czeskich polityków różnych opcji myśl taka pojawiała się od czasu do czasu, nigdy jednak nie inspirując poważniejszych dyskusji. Idea niepodległości oznaczała otwarty bunt przeciwko Austro-Węgrom. Na czele ruchu antyaustriackiego stanął Tomáš Garrigue Masaryk (1850-1937), profesor czeskiego uniwersytetu w Pradze, wówczas poseł z ramienia realistów. Szerszej opinii publicznej stał się znany w latach osiemdziesiątych XIX w., gdy podważył pochodzenie rękopisów královédvorskiego i zelenohorskiego. Po raz

\footnotetext{
17 Zamachu dokonał we Wiedniu dr Friedrich Adler (1879-1960), przyrodnik i polityk socjaldemokratyczny, syn wiedeńskiego lekarza Viktora Adlera. Motywem był protest przeciwko dyktaturze wojskowo-biurokratycznej, której głównym reprezentantem miał być właśnie Stürghk. 18

F. Soukup, 28. říjen1918, s. 354-357.
} 
kolejny zrobiło się o nim głośno w 1899 r. Stanął wówczas w obronie Żyda Leopolda Hilsnera, niesłusznie oskarżonego o zabójstwo chrześcijańskiej dziewczyny i otwarcie wystąpił przeciwko powszechnym w Czechach przesądom religijnym, zwłaszcza dotyczącym mordów rytualnych ${ }^{19}$. Masaryk swoim wystąpieniem mocno naraził się czeskiej opinii publicznej. Spotkał się jednak z poparciem za granicą, zwłaszcza w kręgach syjonistycznych. Idea syjonizmu, według której Żydzi mają naturalne prawo do własnego państwa w Palestynie, była zresztą bliska Masarykowi. Kilka lat przed wybuchem pierwszej wojny światowej Masaryk wystąpił w obronie serbskich polityków, których oskarżono w Chorwacji o szpiegostwo i postawiono przed sądem z Zagrzebiu ${ }^{20}$.

Masaryk długo uważał się za austriackiego patriotę i bronił istnienia monarchii. Nie wiemy dziś dokładnie, czy zmienił zdanie dopiero po wybuchu wojny czy już wcześniej? Bez wątpienia na podstawie własnych obserwacji i rozmów z różnymi politykami doszedł do przeświadczenia, że zwycięstwo Austro-Węgier w wojnie oznaczałoby całkowitą germanizację monarchii. Od tego momentu całą swą ener-

19 Tuż przed Wielkanocą 1899 r. niedaleko miasteczka Polná pod Igławą znaleziono ciało młodej dziewczyny, Anežki Hrůzovej. O zabójstwo oskarżono miejscowego czeladnika żydowskiego pochodzenia. Wśród okolicznych mieszkańców rozeszła się pogłoska, że Hilsner potrzebował krwi koniecznej do wypieku macy na nadchodzące święto paschy. Zabójstwo wywołało w całych Czechach falę antysemickich wystąpień. W atmosferze zbiorowej histerii przysięgli sądu w Kutnej Horze skazali Hilsnera na śmierć. Sprawa trafiła do sądu wyższej instancji. Nowy proces przed sądem w Písku potwierdził wyrok śmierci, jednak cesarz zamienił go na karę dożywotniego więzienia. Hilsner został uwolniony wiosną 1918 r., zmarł w roku 1926. Patrz: T.G. Masaryk, Nutnost revidovati process polenský, Praha 1899; J. Kovtun, Tajuplná vražda. Př́pad Leopolda Hilsnera. Praha 1994.

20 W sierpniu $1908 \mathrm{r}$. aresztowano w Chorwacji 53 osoby, którym w marcu kolejnego roku wytoczono wielki proces. Byli to politycy z tzw. koalicji chorwacko-serbskiej, która opowiadała się za bliską wspólpracą Chorwatów i chorwackich Serbów. Wszystkich oskarżono o zdradę stanu i szpiegostwo na rzecz Serbii. W trakcie procesu wiedeński dziennik „Neue Freie Presse” opublikował serię artykułów austriackiego historyka Heinricha Friedjunga (1851-1920), który na podstawie materiałów przekazanych mu przez ministra spraw zagranicznych Aloisa Lexę von Aehrenthala oskarżał chorwackich Serbów o działalność wywrotową. Sąd w Zagrzebiu skazał 5 X 1909 r. 33 oskarżonych na kary od pięciu do dwunastu lat więzienia. Masaryk, który przez kilka dni obserwował proces osobiście, wystąpił z ich publiczną obroną. Wykazał, że oskarżenie nie ma podstaw i służy jedynie jako pretekst do aneksji Bośni i Hercegowiny. Udowodnił też, że materiały udostępnione przez Aehrenthala są sfabrykowane. Obrona Masaryka doprowadziła do postępowania odwoławczego, $w$ wyniku którego wiele wyroków unieważniono, pozostali skazani zostali później ułaskawieni. Zob. T.G. Masaryk, Der Agramer Hochverratsprocess und die Annexion von Bosnien und Herzegovina, 2. Ausg., Wien 1909; J. Rychlík, M. Perenčević, Dějiny Chorvatska, Praha 2007, s. 226-228. 
gię poświęcił na rzecz jej rozbicia. Jego plan polegał na zainteresowaniu państw Ententy kwestią czeską tak, by powstanie niepodległego państwa czeskiego, rozszerzonego o Słowację, stało się jednym z ich wojennych celów. Sami Czesi i Słowacy mieli pomóc koalicji poprzez zbieranie informacji wywiadowczych i organizację antyaustriackich oddziałów ochotniczych złożonych z czeskich i słowackich jeńców wojennych. Najbliższym współpracownikiem Masaryka stał się jego dawny student Edvard Beneš (1884-1948). Dla stosunków panujących w Austrii charakterystyczny jest fakt, że w czasie gdy Tomáš Masaryk prowadził antyaustriacką działalność za granicą, a jego córka Alicja (Alice 1879-1966) została aresztowana przez władze, syn Jan (1886-1948), późniejszy polityk czechosłowacki, dyplomata i minister spraw zagranicznych, służył w szeregach armii austro-węgierskiej.

Jesienią 1914 r. Masaryk spotkał się potajemnie w Rotterdamie ze szkockim slawistą Robertem Williamem Seton-Watsonem, o którym wiedział, że ma dostęp do brytyjskich kręgów rządowych. Po spotkaniu Seton-Watson opracował memorandum dla Foreign Office, w którym opowiedział się za poparciem samodzielnego państwa czesko-słowackiego ${ }^{21}$. Masaryk powrócił do Pragi, jednak wkrótce znów wyjechał za granicę, tym razem do neutralnych wciąż Włoch, a stamtąd do Szwajcarii. Seton-Watson namówił go na wyjazd do Londynu (Masaryk przeniósł się tam ostatecznie pod koniec września). W kwietniu Masaryk przygotował kolejne memorandum zatytułowane „Niepodległe Czechy”, które Seton-Watson przekazał brytyjskiej dyplomacji i rządom pozostałych państw Ententy ${ }^{22} .6$ VII 1915 r., podczas wykładu w Genewie wygłoszonego w 500. rocznicę spalenia Jana Husa, Masaryk ogłosił program walki o niepodległą Czechosłowację̧23. 14 XI 1915 r. powołano w Paryżu Czeski Komitet Zagraniczny ${ }^{24}$ zastąpiony w lutym 1916 r. Narodową Radą Ziem Czeskich, przemianowaną z kolei na Czechosłowacką Radę Narodową (Conseil National Tchèchoslovaque). Kierownictwo w Radzie objąl formalnie Masaryk, chociaż nadal przebywał w Londynie. W Paryżu tymczasem działał w jego imieniu Beneš, który w 1915 r. uciekł przez Niemcy do Szwajcarii. Wraz z nim pierwszoplanową postacią Rady stał się inny z dawnych studentów Masaryka, Słowak Milan Rastislav Štefánik, astronom, naturalizowany obywatel francuski, który jeszcze przed

21 J. Rychlík, T.D. Marzik, M. Bielik (eds.), R.W. Seton-Watson and His Relations with Czechs and Slovaks. Documents 1906-1951 (RWSW-D), I., Praha-Martin 1995, dok. 61, s. 209-215.

22 RWSW-D, I., dok. 68, s. 223-235.

23 T.G. Masaryk, Válka a revoluce. Články - memoranda - přednášky - rozhovory 1914-1916, Praha 2005, s. 82-83.

24 Tamże, s. 137-139. 
wojną oddał władzom Francji istotne usługi, organizując lotniczą służbę meteorologiczną, a po wybuchu wojny sam wstąpił do lotnictwa. Štefánik, cieszący się zaufaniem rządu francuskiego, otworzył przed Masarykiem i Benešem drzwi do wielu ważnych gabinetów, a za sprawą swej kochanki, Włoszki Giuliany Benzoni, pomógł im dotrzeć do włoskich kręgów rządowych. Na początku 1917 r. Czechosłowacka Rada Narodowa osiągnęła pierwszy sukces dyplomatyczny: 10 stycznia państwa Ententy wydały notę dotyczącą celów wojny, w której znalazła się zapowiedź „wyzwolenia Włochów, Słowian, Rumunów i Czechosłowaków spod obcej przemocy"25. Wzmianka o Czechosłowakach została dodana do gotowego już tekstu w ostatniej chwili właśnie na prośbę Rady. Należy zwrócić uwagę, że ten oględnie sformułowany postulat w żaden sposób nie przesądzal, że państwa Ententy opowiadają się za powstaniem niepodległej Czechosłowacji. Co istotne, 24 stycznia przedstawiciele większości czeskich partii politycznych na żądanie austro-węgierskiego ministra spraw zagranicznych Ottokara Czernina (1872-1932) publicznie odrzucili notę, zapewniając, że „naród czeski tak w przeszłości, obecnie jak i w przyszłości widzi się tylko pod berłem habsburskim"26.

Antyaustriacki ruch za granicą od początku dostrzegał konieczność tworzenia po stronie Ententy oddziałów zbrojnych, do których mieli wstępować Czesi i Słowacy mieszkający za granicą, służący w armii austro-węgierskiej i wzięci do niewoli lub dezerterzy. Istotne dla tych działań było wsparcie czeskich i słowackich środowisk emigracyjnych. Już 1 VIII 1914 r. powołano we Francji kompanię Nazdar! (Czołem!), którą włączono do Legii Cudzoziemskiej (to dlatego czescy i słowaccy ochotnicy byli później nazywani legionistami ${ }^{27}$. Kompania ta została w 1915 r. rzucona do walki przeciwko wojskom niemieckim pod Arras, gdzie większość jej członków poległa. 20 VIII 1914 r. rosyjskie dowództwo wydało zgodę na utworzenie tzw. Drużyny Czeskiej, do której wstępowali początkowo obywatele rosyjscy narodowości czeskiej i słowackiej, a od października także Czesi i Słowacy wypuszczani z rosyjskiej niewoli. „Drużynnicy” byli wysyłani w mundurach austro-węgierskich na linię frontu, by zbierać informacje wywiadowcze. W 1916 r. Drużynę przemianowano na Czechosłowacki Pułk Strzelecki, a 21 IV 1916 r. car Mikołaj II wydał zgodę na sformowanie w Rosji armii czechosłowackiej, do czego jednak nigdy nie doszło ${ }^{28}$.

\footnotetext{
25 E. Beneš, Světová válka a naše revoluce, III, Dokumenty, 3. wyd., Praha 1931, dok. 88, s. 283.

26 Tamże, dok. 90, s. 287.

T. G. Masaryk, Světová revoluce, Praha 2005, s. 227.
} 
Rząd rosyjski nie był w istocie zainteresowany budową większych oddziałów rekrutujących się z dawnych jeńców z dwóch powodów. Po pierwsze, Rosja miała dość rekrutów spośród własnych obywateli i lepiej było skierować Czechów i Słowaków, często świetnie wykwalifikowanych, do pracy w przemyśle. Po drugie obawiała się otwarcie poprzeć postulaty Czechów, bojąc się, że mogłoby to mieć „zły wpływ” na nierosyjskie narody imperium. Latem 1916 r. rząd francuski zgodził się na tworzenie czesko-słowackich oddziałów na swoim terytorium. Czesi i Słowacy nie walczyli jednak na froncie zachodnim, trudno więc było o rekrutów spośród jeńców wojennych, stąd do Francji miała być przerzucona część ochotników z Rosji. W styczniu 1917 r. na powołanie armii złożonej z Czechów i Słowaków zdecydował się warunkowo także rząd włoski. Dla byłych jeńców wstąpienie do oddziałów czesko-słowackich ${ }^{29}$ wiązało się z ogromnym ryzykiem i wymagało przekonania, że walczy się o słuszną sprawę. Prawo i konwencje międzynarodowe nie przewidują statutu jeńca wojennego dla osoby walczącej przeciwko państwu, którego jest obywatelem. W przypadku, gdy walczący po stronie państw Ententy Czech lub Słowak znalazł się w rękach austriackich, czekała go bezwzględnie kara śmierci.

Ogromne znaczenie dla zagranicznego ruchu antyaustriackiego miała postawa czeskiej i słowackiej emigracji w USA. Większość czeskich organizacji emigracyjnych, z wyjątkiem Związku Katolików Czeskich, już 2 IX 1914 r. utworzyła Czeskie Stowarzyszenie Narodowe. Słowacka emigracja stworzyła jednolitą organizację, Ligę Słowacką w Ameryce, jeszcze w 1907 r. Liga była gotowa poprzeć działania Masaryka, miała jednak odmienną wizję kształtu przyszłego państwa. Podczas gdy Masaryk, Beneš i Štefánik rozumieli pojęcie „wspólnego państwa” jako państwa czeskiego poszerzonego o ziemie słowackie, Liga opowiadała się za unią dwóch suwerennych państw, na kształt Austro-Węgier. Rozmowy co do przyszłości państwa czesko-słowackiego, prowadzone między Czeskim Stowarzyszeniem Narodowym a Ligą Słowacką w Ameryce odbyły się 22 X 1915 r. w Cleveland. Ich efektem było porozumienie zwane clevelandzkim, w którym czeska emigracja przyjęła program „połączenia narodu czeskiego i słowackiego w federacyjnym związku państw, z pełną autonomią Słowacji, z własnym sejmem, własną administracją państwową, pełną swobodą kulturową, a zatem i pełnym prawem do używania języka słowackiego,

29 Przymiotnik „czechosłowacki” stosowany jest w niniejszym przekładzie w odniesieniu do Czechosłowacji, czyli powstałego w 1918 r. wspólnego państwa Czechów i Słowaków, w pozostałych przypadkach stosuje się przymiotnik „czesko-słowacki” (chyba że wynika to z tłumaczenia nazw własnych). W języku czeskim takie rozróżnienie właściwie nie istnieje, w obu przypadkach używa się tej samej formy przymiotnika: československý (przyp. tłum.). 
własną administracją finansową i polityczną, z państwowym językiem słowackim"30. Liga Słowacka zebrała także niemałe fundusze na wsparcie działań prowadzonych przez Masaryka. W 1916 r. do paryskiej Rady Narodowej dołączył Słowak Štefan Osuský (1889-1973), krajan Štefánika i podobnie jak on ewangelik. Ku zaskoczeniu Beneša Osuský nie przyjął bezwarunkowo idei zjednoczenia Czechów i Słowaków. To z jego inspiracji zmieniono nazwę Rady Narodowej Ziem Czeskich na Czechosłowacką Radę Narodową, nie zgadzał się bowiem z poglądem, że Słowacja jest częścią ziem czeskich, jak Morawy czy Śląsk ${ }^{31}$. Wszystko to było zapowiedzią późniejszych sporów i konfliktów Czechów i Słowaków wokół kształtu wspólnego państwa.

6 IV 1917 r. Stany Zjednoczone przystąpiły do wojny po stronie państw Ententy. Organizacje czeskie i słowackie wezwały swoich członków i sympatyków, by - jeśli tylko nie zostaną powołani do armii amerykańskiej - wstępowali do jednostek ochotniczych we Francji i Włoszech.

Rosja nie była przygotowana na długą i wyczerpującą wojnę. Od końca $1916 \mathrm{r}$. we wszystkich miastach przemysłowych wybuchały strajki i bunty głodowe. 8 III 1917 r. (23 II w kalendarzu juliańskim) rozpoczął się strajk w Piotrogrodzie, który w kolejnych dniach rozszerzył się na inne obszary kraju. Władza zdecydowała się rzucić na strajkujących wojsko, co tylko pogorszyło sytuację: 11 III (26 II) wybuchło antycarskie powstanie. Po trzech dniach walk, 13 (1) III 1917 r. carat w Rosji upadł. Dzień później Mikołaj II podpisał akt abdykacji, władzę w imperium przejął Rząd Tymczasowy. Swoją pozycję wzmocniły także powstałe w czasie rewolucji rady robotnicze. Istniejący system dwuwładzy szybko doprowadził do chaosu w państwie.

Czechosłowacka Rada Narodowa z ulgą przyjęła wydarzenia w Rosji. Masaryk liczył na to, że nowy rząd przestanie sabotować tworzenie czesko-słowackich oddziałów ochotniczych. Wkrótce wsiadł na statek, by przez Skandynawię dotrzeć do Rosji, gdzie powołano miejscową reprezentację Rady. Minister spraw zagranicznych Rządu Tymczasowego Paweł Milukow 24 III 1917 r. jako pierwszy oficjalny przedstawiciel państw Ententy wprost opowiedział się za powstaniem niepodległego państwa czechosłowackiego. Dwa dni później rząd księcia Gieorgija Lwowa wydał zgodę na formowanie armii czesko-słowackiej w Rosji. Władze musiały w tym czasie stawić czoła kryzysowi w armii. Bolszewicy, kierowani przez Włodzimierza Lenina (1870-1924),

\footnotetext{
30 DSNIŠ, I., dok. 139, s. 445-447.

31 Š. Osuský, How Czecho-Slovakia was born, [in:] J. M. Kirschbaum (ed.), Slovakia in the $19^{\text {th }}$ and $20^{\text {th }}$ Centuries, Toronto 1973, s. 87.
} 
który dzięki niemieckiej pomocy wrócił z emigracji w Szwajcarii, prowadzili wśród żołnierzy agitację na rzecz jak najszybszego zakończenia wojny „bez aneksji i kontrybucji”. Chaos w armii wzmagała także niemiecka propaganda, która liczyła na wycofanie się Rosji z wojny. Na froncie dochodziło do przypadków „bratania się” niemieckich i rosyjskich żołnierzy, inspirowanych często przez niemiecki wywiad. Rosyjskie oddziały, w których powstały rady żołnierskie, samowolnie opuszczały linię frontu.

Minister wojny Aleksander Kiereński, późniejszy premier Rządu Tymczasowego, zdecydował się zadbać o resztki dyscypliny w armii i z początkiem lata zorganizował ofensywę przeciw armii austro-węgierskiej pod Tarnopolem. W tej sytuacji trzy pułki utworzonej właśnie Czechosłowackiej Brygady Strzeleckiej okazały się niezwykle pomocne. Brygada, dowodzona przez pułkownika Wiaczesława Trojanowa, została przerzucona 2 VII 1917 r. pod Zborów w Galicji, gdzie z powodzeniem wbiła się $5 \mathrm{~km}$ za linię frontu, zdobywając 20 dział i wiele sprzętu wojskowego oraz biorąc do niewoli 4 tys. żołnierzy przeciwnika. Bitwa pod Zborowem była pierwszą samodzielną operacją oddziałów czesko-słowackich, a 2 lipca był w okresie I Republiki Czechosłowackiej obchodzony jako Dzień Armii. Paradoksem jest, że naprzeciw brygady czechosłowackiej stał 35. pułk pieszy z Pilzna i 75. pułk pieszy z Jindřichowego Hradca. Czesi walczyli więc przeciw Czechom $^{32}$.

Zwycięstwo pod Zborowem zostało zaprzepaszczone przez oddziały rosyjskie, które odmówiły dalszej walki i opuszczały linię frontu. Ofensywa Kiereńskiego załamała się, a Czechosłowacka Brygada Strzelecka została wycofana. Sukces Czechów i Słowaków wpłynął jednak na dowództwo rosyjskie, które zezwoliło im na utworzenie kolejnej brygady. Na początku października istniał już samodzielny Korpus Czechosłowacki. Wkrótce doszło jednak do przewrotu bolszewickiego. W nocy z 6 na 7 XI (24/25 X) 1917 r. oddziały czerwonogwardzistów zajęły strategiczne punkty w Piotrogrodzie, doprowadzając do upadku Rządu Tymczasowego. Władza przeszła w ręce Rady Komisarzy Ludowych opanowanej przez bolszewików. Przewrót, zwany rewolucją październikową, miał w stolicy spokojny przebieg, do walk doszło za to w Moskwie, a ich świadkiem był przebywający tam akurat Masaryk. Nowy rząd wydał 26 X (8 XI) 1917 r. „dekret o pokoju”, przystępując do realizacji planu wycofania się Rosji z wojny i opowiedział się za „prawem narodów do samostanowienia aż do oderwania się".

Idea pokoju „bez aneksji i kontrybucji” była dla czesko-słowackiego ruchu oporu nie do przyjęcia, oznaczała bowiem powrót do stanu sprzed wybuchu wojny. Pyta-

32 I. Šedivý, Češi, české země a Velká válka, s. 117-119. 
niem pozostaje, do jakiego stopnia sami bolszewicy traktowali to hasło na poważnie, bowiem jego realizacja stałaby w sprzeczności z „prawem narodów do samostanowienia”. Z drugiej strony trudno było zaakceptować prawo narodów do „oderwania się", jego realizacja niosłaby bowiem ryzyko podziału ziem czeskich i przyłączenia ich części do Niemiec. Dekret o prawach narodów niósł ze sobą jeszcze jedną komplikację. Ukraińska Rada Narodowa ogłosiła pełną suwerenność Ukrainy i Czesi musieli negocjować z nią statut oddziałów czesko-słowackich stacjonujących właśnie na jej terytorium. Prawdziwy popłoch zapanował jednak wraz z podpisaniem w Brześciu Litewskim rozejmu rosyjsko-niemieckiego i rozpoczęciem negocjacji, które doprowadziły do zawarcia separatystycznego pokoju państw centralnych najpierw z Ukrainą (9 II 1918 r.), a następnie z Rosją (3 III 1918 r.). Wśród uzgodnień pokoju brzeskiego, oznaczającego faktyczną kapitulację Rosji, znalazło się uwolnienie jeńców austro-węgierskich oraz zobowiązanie do nie utrzymywania na terytorium rosyjskim obcych formacji wojskowych walczących przeciwko państwom centralnym. Nad żołnierzami czeskimi i słowackimi zawisła groźba rozbrojenia, wydalenia do Austrii i pewnej śmierci.

Masaryk opuścił Rosję i przez Syberię i Japonię wyjechał do Ameryki. Jednak przed wyjazdem udało mu się wynegocjować uznanie oddziałów czesko-słowackich za część Armii Czechosłowackiej we Francji. Reprezentacja Czechosłowackiej Rady Narodowej w Rosji zawarła z nowymi władzami porozumienie dotyczące ich ewakuacji do portu we Władywostoku, skąd miały być przetransportowane na front zachodni. Do Francji przedostała się jednak tylko niewielka część oddziałów. Większość żołnierzy stała się, chcąc nie chcąc, uczestnikami rosyjskiej wojny domowej33.

\section{Działalność antyaustriacka w Czechach}

W grudniu 1914 r., krótko po tym jak Tomáš Masaryk opuścił Czechy, zawiązany został krajowy ośrodek oporu nazwany „Mafią”34. Należeli do niej członek partii

\footnotetext{
3314 V 1918 r. na stacji kolejowej w Czelabińsku doszło do incydentu między oddziałami czeskimi a grupą przewożonych tamtędy jeńców niemieckich, węgierskich i rumuńskich. Władze bolszewickie aresztowały kilku Czechów, którym zarzucono odpowiedzialność za incydent. Trzy dni później towarzysze broni odbili ich z aresztu, zajmując przy okazji kilka ważnych punktów w mieście. Bolszewicy potraktowali te wydarzenia jako pretekst do zerwania umowy z Czechosłowacką Radą Narodową (przyp. tłum.).

34 O „Mafii” patrz np.: J. Hajšman, Česká mafie. Vzpomínky na odboj doma, Praha 1932; M. Paulová, Dějiny Mafie I. - II., Praha 1937, 1939.
} 
realistycznej Přemysl Šámal (1867-1941), Edvard Beneš, przywódca organizacji „Sokół” Josef Scheiner (1861-1932), Karel Kramář (1860-1937) i Alois Rašín (1867-1923). Kontakty z „Mafią” utrzymywał też przywódca agrarystów František Soukup (1871-1940), który wbrew oficjalnej proaustriackiej orientacji kierownictwa ČSSD z Bohumírem Šmeralem (1880-1941) reprezentował tzw. nurt narodowy zabiegający o czeską niezależność. Z czasem „Mafia” stworzyła sieć tajnych współpracowników, także wśród czeskich urzędników w urzędzie namiestnika i dyrekcji policji, co umożliwiło zbieranie informacji wywiadowczych przydatnych państwom Ententy. Dostarczali je na zachód specjalni kurierzy, dla których udało się uzyskać paszporty na podróż do państw neutralnych. Z powrotem przywozili informacje i wskazówki od zagranicznego kierownictwa. Proklamowanie niepodległej Czechosłowacji miało nastąpić na polecenie Czechosłowackiej Rady Narodowej w końcowej fazie wojny, gdy porażka Austro-Węgier będzie przesądzona. Co do dalszych działań członkowie „Mafii” nie byli jednak zgodni. Karel Kramář proponował, by na tronie Czech zasiadł któryś z Romanowów. Jego nadzieje na realizację tych planów wzrosły, gdy jesienią 1914 r. oddziały rosyjskie wkroczyły na Słowację i pojawiła się szansa ich marszu ku Morawom i Czechom. Naczelny wódz Mikołaj Mikołajewicz rozpowszechniał przy tym manifest carski, w którym zapowiadano oswobodzenie Słowian. Większość krajowego ruchu antyaustriackiego zorientowana była jednak na Zachód. Sam Masaryk w dokumencie dla Foreign Office dopuszczał możliwość, by czeskim królem został książę Danii. Z kolei Soukup i jego socjaldemokratyczni towarzysze w ogóle odrzucali ideę monarchii uznając, że niepodległe państwo czeskie powinno być republiką. Gdy wiosną 1915 r. armia rosyjska znalazła się w odwrocie, koncepcja Kramářa upadła.

Tajna policja austriacka dość szybko wpadła na trop „Mafii”. 21 V 1915 r. aresztowano Kramářa, a wkrótce w areszcie znaleźli się także Scheiner i Rašín. Jesienią ujęto kolejnych działaczy niepodległościowych, internowano także córkę Masaryka Alicję i żonę Beneša Hanę (sam Beneš zdołał uciec do Szwajcarii). Na wolności pozostał tylko Šámal, któremu udało się stopniowo odbudować struktury kierownicze „Mafii” i jej siatkę wywiadowczą.

Podczas gdy Scheiner po dwóch miesiącach odzyskał wolność, Kramář, Rašín i dwóch członków siatki wywiadowczej, redaktor „Narodních listów” Vincenc Červinka i urzędnik Josef Zamazal, stanęli przed sądem oskarżeni o szpiegostwo i zdradę stanu. Proces rozpoczął się 6 XII 1915 r., a zakończył równo pół roku później wyrokami śmierci przez powieszenie. Wszyscy skazani odwołali się od wyroku, jednak Najwyższy Sąd Wojskowy 20 XI 1916 r., po sześciodniowym procesie, utrzy- 
mał zasądzone kary ${ }^{35}$. Czekano tylko, czy cesarz potwierdzi wyrok, czy też zechce go złagodzić. Jako że sąd nie poparł wniosku o łaskę, wydawało się, że nic już nie może uratować skazanych przed szubienicą. Jednak dzień później, 21 listopada, Franciszek Józef I zmarł w 86 roku życia. Jego następca, Karol I (1916-1918), nie chciał zaczynać swego panowania od egzekucji i zdecydował się zamienić wyroki śmierci na kary więzienia: dla Kramářa 15 lat, Rašína 10 lat, Červinki i Zamazala po 6 lat ${ }^{36}$.

\section{Czeska aktywność polityczna w latach 1917-1918}

Karol I, koronowany 30 XII 1916 r. na króla Węgier jako Karol IV, nie miał, w odróżnieniu od swych dowódców, wątpliwości co do dalszego przebiegu wojny. Jego własne doświadczenia frontowe kazały mu uznać, że zasoby ludzkie i materialne Austro-Węgier dawno się wyczerpały i należy czym prędzej doprowadzić do jej zakończenia. Z jednej strony próbował przekonać do swej koncepcji cesarza Wilhlema, z drugiej zaczął szukać kontaktów z władzami Francji. Wykorzystał do tego swoją żonę Zytę, która pochodziła z rodu Bourbon-Parma, zaś jej bracia, książęta Sykstus i Xavier służyli jako ochotnicy w stopniu porucznika w armii belgijskiej, mając dostęp do francuskich kręgów rządowych, włącznie z prezydentem Raymondem Poincarém. Rozmowy pokojowe rozpoczęto pod koniec stycznia 1917 r. Utrzymywano je w tajemnicy zwłaszcza przed Niemcami, które miały się o nich dowiedzieć dopiero w przypadku zawarcia porozumienia ${ }^{37}$.

Antywojenne nastroje panujące w Rosji i decyzje Rządu Tymczasowego liberalizujące życie polityczne wpłynęly także na sytuację w Austro-Węgrzech. Nierosyjskie narody imperium zaczęły coraz głośniej domagać się prawa do samostanowienia i niepodległości. Podczas gdy Wilhelm II widział w rewolucji lutowej szansę na przegraną Rosji w wojnie, Karol I obawiał się rozprzestrzenienia żądań społecznych i narodowościowych na inne kraje. Bunty głodowe, od których zaczął się upadek caratu, były w 1917 r. w Austro-Węgrzech, a zwłaszcza na ziemiach czeskich, na porządku dziennym. Młody cesarz miał świadomość, że jeśli chce uratować monarchię przed rozpadem, musi zakończyć rządy dyktatury wojskowo-biurokratycznej, przywrócić parlamentaryzm i przeprowadzić reformy wychodzące naprzeciw postulatom poszczególnych narodów. Na początku 1917 r. ograniczono uprawnienia wojska

\footnotetext{
35 F. Soukup, 28. řijen, s. 169-181.

36 Tamże, s. 182.

37 J. Galandauer, Karel I. Poslední český král, s. 159-164.
} 
wobec administracji cywilnej. Cesarz sam stanął na czele armii w miejsce arcyksięcia Fryderyka, który formalnie został jego zastępcą, odwołując także Conrada von Hötzendorfa. Z obozów internowania zwolniono szereg osób, w tym przywódcę narodowych socjalistów Václava Klofáča. Karol I sprzeciwił się także planom premiera Clam-Martinica, który chciał na podstawie dekretów rządowych doprowadzić do utworzenia niemieckiej „Austrii zachodniej”. Wreszcie 26 IV 1917 r. cesarz wydał manifest zwołujący na dzień 30 maja Radę Państwa.

Zniesienie dyktatury wojskowo-biurokratycznej i zapowiedź zwołania parlamentu zaktywizowały na nowo czeskie życie polityczne. Posłowie, z uwagi na swe wcześniejsze deklaracje lojalności wobec monarchii, nie cieszyli się jednak zaufaniem społeczeństwa. W maju 1917 r. 222 czeskich pisarzy i działaczy kulturalnych wystąpiło przeciwko dotychczasowej polityce Związku Czeskiego i wezwało posłów, by złożyli mandaty, jeśli nie zamierzają walczyć o interesy narodowe ${ }^{38}$. Podczas inauguracyjnej sesji Rady Państwa przygotowali więc zdecydowane wystąpienia, w których domagali się połączenia ziem czeskich w jeden organizm państwowy. Podczas przygotowań do inauguracji słowaccy politycy Vavro Šrobár (1867-1950) i Anton Štefánek (1877-1964) wystąpili do Związku Czeskiego, by w przemówieniach posłów znalazł się także postulat przyłączenia Słowacji do państwa czeskiego. Po początkowym wahaniu większość czeskich posłów poparła ten pomys1 ${ }^{39}$.

$30 \mathrm{~V} 1917$ r. po uroczystym rozpoczęciu obrad parlamentu, poseł František Staněk (1867-1936) odczytał w imieniu Związku Czeskiego oczekiwane z napięciem stanowisko, w którego zakończeniu stwierdzono: „Będziemy na czele swego ludu domagać się zjednoczenia wszystkich gałęzi narodu czechosłowackiego w demokratycznym państwie czeskim, obejmującym także gałąź słowacką żyjącą w nieprzerwanym związku z historyczną ojczyzną czeską" ${ }^{40}$. Zgodnie z poczynionymi uprzednio ustaleniami tuż po tym wystąpił słoweński poseł katolicki Anton Korošec (1872-1940) odczytując przygotowane w podobnym duchu stanowisko Południowosłowiańskiego Klubu Poselskiego, w którym domagano się zjednoczenia w jednym państwie Serbów, Chorwatów i Słoweńców ${ }^{41}$.

\footnotetext{
38 Tekst patrz: J. Galandauer, Vznik Československé republiky, dok. 9, s. 283-287.

39 V. Šrobár, Pamäti z vojny a z väzenia 1914-1918, Praha 1922, s. 76; M. Hronský, M. Pekník, Martinská deklarácia. Cesta slovenskej politiky k vzniku Česko-Slovenska, Bratislava 2008, s. $153-157$.

40 Stenographische Protokolle, Haus der Abgeordneten, I. Sitzung der XXII Session am $30 \mathrm{~V}$ 1917, s. 34

41 Tamże, s. 35.
} 
Postulat zjednoczenia ziem czeskich ze Słowacją, podobnie jak postulat utworzenia państwa południowosłowiańskiego, był nie do spełnienia w istniejących warunkach ustrojowych. Cesarz Karol jako król Węgier był na podstawie przysięgi koronacyjnej zobowiązany do walki o niepodzielność ich terytorium, a kompetencje Rady Państwa nie obejmowały węgierskiej części monarchii. Opowiadając się za jednością Czech i Słowacji czescy posłowie domagali się w istocie utworzenia niezależnego państwa, nawet jeśli nie mieli wówczas takiej świadomości. Deklaracja z 30 maja była więc aktem decydującym. W dyskusji nad stanowiskiem poseł Antonín Kalina (1870-1922) w imieniu Postępowej Partii Państwowoprawnej i czterech parlamentarzystów partii narodowo-socjalistycznej wprost zażądał utworzenia odrębnego państwa. Przeciwko stanowisku opowiedzieli się jedynie klerykalni posłowie ludowi.

Zgodnie z oczekiwaniami przedstawiony postulat wywołał natychmiastowy sprzeciw premiera Węgier Istvána Tiszy (1861-1918). Próbował on namówić przedstawicieli Słoweńskiej Partii Narodowej do złożenia jakiejś prowęgierskiej deklaracji, jednak przewodniczący partii, Matúš Dula (1846-1926), zdecydowanie odrzucił taką możliwośćc ${ }^{42}$.

W ramach polityki łagodzenia stosunków narodowościowych w państwie na początku lata 1917 r. ogłoszono amnestię, dzięki której na wolności znaleźli się m.in. Kramář i Rašín. Nowy rząd Ernesta Seidlera (1862-1931), powołany 23 czerwca, zamierzał zreformować ustrój państwa i znowelizować konstytucję. Szybko okazało się, że sprzeczności między narodami wydają się nie do pogodzenia, a już szczególnie trudno będzie znaleźć rozsądne rozwiązanie konfliktu czesko-niemieckiego. Czesi obstawali za połączeniem ziem czeskich i Słowacji, Niemcy za stworzeniem odrębnej prowincji w Czechach. Wykluczało to w istocie jakikolwiek kompromis.

Idea powstania niepodległego państwa czeskiego zyskiwała tymczasem coraz więcej zwolenników. 21 VII 1917 r. odbyło się w Wiedniu tajne spotkanie czeskich agrarystów z grupą polityków słowackich skupionych wokół Milana Hodžy (1878-1944), powtórzone jeszcze 12 września. Efektem rozmów było porzucenie przez agrarystów polityki aktywistycznej. Podobną postawę przyjęli też czescy socjaldemokraci. Podczas posiedzenia prezydium Komitetu Wykonawczego ČSSD, które zebrało się 28 września, proaustriacki Bohumír Šmeral zmuszony został do rezygnacji z kierowania partią, a do jej władz weszli zwolennicy niepodległości. 26 września odbyło się kolejne spotkanie czeskich i słowackich polityków z udziałem reprezentanta słowackich socjaldemokratów Emanuela Lehockiego (1876-1930), podczas którego opowiedziano 
się jednoznacznie za niepodległością. W ten sposób idea samodzielnego państwa czeskiego zyskała poparcie dwóch najsilniejszych środowisk politycznych - agrarystów i socjaldemokratów. 2 II 1918 r. Młodoczesi połączyli się z Partią Postępową, Partią Radykalnie Państwowoprawną i Morawską Partią Ludową tworząc wspólną prawicową Czeską Demokrację Państwowoprawną (Česká státopravní demokracie), która bezwarunkowo opowiedziała się ze pełną niezależnością Czech. Austria nie miała już po swojej stronie żadnej liczącej się siły politycznej ${ }^{43}$.

6 I 1918 r. postulat połączenia ziem czeskich i Słowacji znalazł się we wspólnej deklaracji czeskich posłów do sejmów krajowych i Rady Państwa. Zażądano w niej udziału delegacji Czechów i Słowaków w konferencji pokojowej, co łączyło się $\mathrm{w}$ istocie $\mathrm{z}$ uznaniem suwerenności ich ziem ${ }^{44}$. Jak można było oczekiwać, niemieccy posłowie z ziem czeskich odrzucili ten postulat i powtórzyli żądanie wykrojenia z Czech prowincji niemieckiej z własnym sejmem.

\section{Powstanie niepodległego państwa czesko-słowackiego}

Wiosna 1918 r. przyniosła fiasko rozmów pokojowych prowadzonych przez Sykstusa i Xaviera Burbonów. Francja domagała się zwrotu Alzacji i Lotaryngii, a wiadomym było, że na ten warunek Niemcy nigdy się nie zgodzą. Po zawarciu pokoju brzeskiego szef austriackiej dyplomacji Ottokar Czernin, inaczej niż cesarz, stał się zwolennikiem dalszego prowadzenia wojny po stronie Niemiec aż do jej zwycięskiego końca. $\mathrm{W}$ tym przekonaniu umocniła go zwycięska ofensywa armii niemieckiej na froncie zachodnim rozpoczęta 21 marca oraz negocjacje Niemiec z Rumunią zakończone podpisaniem rozejmu 5 marca, a następnie traktatu pokojowego 7 maja. W przemówieniu do wiedeńskiej Rady Miejskiej 2 IV 1918 r. Czernin, potomek starego czeskiego rodu Černínów, wystąpił zdecydowanie przeciwko postulatom Czechów. Odrzucił nie tylko deklarację z 6 stycznia, ale mówił też o zdradzie Czechów, którzy odmawiają wspólnej walki na rzecz państw centralnych ${ }^{45}$. Czernin dolał jedynie oliwy do ognia, doprowadzając do tego, że przeciwko Austrii zaczęli występować nawet lojalni dotąd katolicy czescy i ostatni Staroczesi. W reakcji na wystąpienie Czernina 13 IV 1918 r. w praskim Domu Miejskim (Obecní dům) przedstawiciele czeskich

43 J. Rychlík, 1918 - Rozpad Rakouska-Uherska, s. 154-155; Z. Kárník, Socialisté na rozcestí. Habsburk, Masaryk či Šmeral?, Praha 1968, s. 132-133.

44 E. Beneš, Světová válka, III., dok. 107, s. 318-321.

45 J. Galandauer, Karel I., s. 214. 
środowisk politycznych i kulturalnych złożyli tzw. Przysięgę Narodową (Národní prŕsaha). Jej tekst, w którym zawarto postulat niepodległości państwa, napisał jeden z przywódców socjaldemokracji František Soukup, a odczytał nestor czeskich pisarzy Alois Jirásek (1851-1930) ${ }^{46}$. Otwarte żądanie pełnej suwerenności pojawiło się publicznie podczas obchodów 1 Maja, na które władze zgodziły się po raz pierwszy od wybuchu wojny. Podczas zgromadzenia w Liptovskim sv. Mikulášu Vavro Šrobár wezwał do połączenia Słowacji z ziemiami czeskimi ${ }^{47}$.

W swoim wystąpieniu przed Radą Miejską Wiednia Czernin zdradził, że francuski premier Georges Clemenceau zaproponował w imieniu Francji rozmowy pokojowe. W odpowiedzi Clemenceau ujawnił dokumenty z których wynikało, że to Austro-Węgry wystąpiły z propozycją rozmów i że stało się tak z inicjatywy samego cesarza. Efektem był wybuch tzw. Sprawy Sykstusa - cesarz i jego żona stali się obiektem ataków ze strony niemieckich nacjonalistów a także samego Czernina. W decydującym momencie Karol I popełnił fatalny błąd: zaprzeczył, by stał za rozmowami pokojowymi i podobnie jak Czernin, który podał się właśnie do dymisji, opowiedział się za dalszym prowadzeniem wojny. $10 \mathrm{~V} 1918$ r. został zmuszony pokajać się przed cesarzem Wilhelmem II, a jego Canossą stało się belgijskie Spa. Trzy dni później obaj władcy podpisali umowę, która oznaczała przejęcie przez Niemcy pełnej kontroli nad armią Austro-Węgier. Miała być ona użyta także do przeprowadzenia decydującej ofensywy na froncie zachodnim, przy czym dowództwo niemieckie jednoznacznie zapowiedziało, że nie życzy sobie w jej szeregach Czechów ${ }^{48}$.

Fiasko rozmów pokojowych zmieniło nastawienie Ententy do kwestii czeskiej. Do tej pory istniała nadzieja na separatystyczny pokój z Austro-Węgrami, jednak Sprawa Sykstusa pokazała jednoznacznie, że celem wojny musi być rozbicie monarchii habsburskiej. Między 8 a 10 IV 1918 r. odbył się w Rzymie „Kongres uciśnionych narodów Austro-Węgier”, podczas którego przedstawiciele poszczególnych narodów obiecali sobie wzajemne poparcie. Przedstawiony w jego trakcie plan przewidywał powstanie niepodległej Czechosłowacji, Jugosławii i Polski ${ }^{49}$.

Na przełomie wiosny i lata 1918 r. monarchia habsburska zaczęła chwiać się w posadach. Kolejne narody powoływały swoje rady lub komitety narodowe z zadaniem przejęcia władzy gdy tylko będzie to możliwe. $24 \mathrm{~V} 1918 \mathrm{r}$. w Turčianskim sv.

\footnotetext{
46 F. Soukup, 28. ř́ijen, II. díl, s. 655-658.

47 M. Hronský, M. Pekník, Martinská deklarácia, s. 220. DSNIŠ, I., dok. 148, s. 470-472.

48 J. Galandauer, Karel I., s. 201.

49 E. Beneš, Světová válka a naše revoluce. II. Praha 1927, s. 105-114.
} 
Martinie odbyło się tajne posiedzenie władz Słowackiej Partii Narodowej z udziałem reprezentantów pozostałych środowisk politycznych. Ustalono, że Słowacja odłączy się od Węgier i zostanie zjednoczona z ziemiami czeskimi ${ }^{50}$. Informację o poczynionych ustaleniach natychmiast przekazano do Pragi. 12 IX 1918 r. podczas spotkania w Budapeszcie kierownictwo partii powołało nowy organ naczelny - Słowacką Radę Narodową. Przewodniczący SPN, Matúš Dula porozumiał się z przedstawicielami pozostałych partii co do planu przejęcia władzy na ziemiach słowackich. Tymczasem w Czechach doszło 13 lipca do zmian w Komitecie Narodowym, w jej skład weszli przedstawiciele wszystkich partii politycznych proporcjonalnie do wyników uzyskanych w wyborach z $1911 \mathrm{r}$. Rada, w porozumieniu z zagranicznym ruchem antyaustriackim, miała przygotować się do objęcia władzy w kraju ${ }^{51}$.

Decydujące znaczenie dla powstania Czechosłowacji miały wydarzenia za granicą. Tomáš Masaryk nawiązał w trakcie swojego pobytu w Stanach Zjednoczonych kontakt $\mathrm{z}$ organizacjami emigracyjnymi, które miały pomóc mu w dotarciu do kręgów rządowych, w tym do samego prezydenta Wilsona. Rozmowy z emigracją nie były proste, Liga Słowacka nadal stała na stanowisku, że Słowacja nie może być wprost przyłączona do Czech, lecz musi zachować atrybuty własnej państwowości. 30 maja Masaryk spotkał się w Pittsburghu z przedstawicielami Ligi, Czeskiego Stowarzyszenia Narodowego i Stowarzyszenia Katolików Czeskich. Efektem spotkania była tzw. umowa pittsburska przewidująca, że Czechosłowacja będzie państwem o ustroju republikańskim, w którym Słowacja zachowa pełną autonomię. Liga Słowacka potwierdziła swoje poparcie dla Masaryka jako przywódcy Czechosłowackiej Rady Narodowej ${ }^{52} .19$ czerwca Masaryk spotkał się w Białym Domu z Woodrowem Wilsonem i przekonał go do swoich planów. Wkrótce nawiązał także kontakt z przywódcą rusińskiej emigracji Grigorijem Żatkowiczem (1886-1967), z którym rozmawiał o włączeniu do Czechosłowacji Rusi Podkarpackiej. Żatkowicz w tej sprawie rozmawiał też z prezydentem USA Woodrowem Wilsonem ${ }^{53}$; faktyczne jednak włączenie tych ziem do państwa czechosłowackiego w 1919 r. było raczej wynikiem powojennej sytuacji międzynarodowej niż amerykańskich rozmów Masaryka ${ }^{54}$.

50 DSNIŠ, I., dok. 150, s. 480.

51 E. Beneš, Světová válka, III., dok. 141, s. 396-398.

52 DSNIŠ, I., dok. 152, s. 485-487.

53 Archiv Ústavu T.G. Masaryka (AÚTGM), Praha, f. TGM-R (republika), Podkarpatská Rus, k. 400, fasc. 1 (1918).

54 AÚTGM, f. TGM-R, Podkarpatská Rus, k. 400, fasc. 2 (1919) patrz też J. Rychlík, M. Rychlíková, Podkarpatská Rus v dějinách Československa 1918-1946. Praha 2016, s. 35-37. 
Tymczasem wydarzenia w Europie zaczęły toczyć się w coraz szybszym tempie. We Francji pojawiły się wojska amerykańskie, co wyraźnie zmieniło układ sił na korzyść Ententy. Między 18 lipca a 6 sierpnia armia niemiecka poniosła ostateczną klęskę w tzw., drugiej bitwie nad Marną. Niecałe trzy tygodnie wcześniej, 29 czerwca, Francja, jako pierwsze państwo europejskie, uznała Czechosłowacką Radę Narodową jako przedstawiciela nieistniejącego jeszcze państwa czechosłowackiego, 9 sierpnia podobną deklarację złożył rząd brytyjski, a 2 września Stany Zjednoczone ${ }^{55}$.

We wrześniu 1918 r. nic już nie było w stanie uratować Austro-Węgier. Po porażce z wojskami brytyjskimi i francuskimi pod Dobro Poljem w Macedonii (14 września) Bułgaria zdecydowała się na rozejm z Ententą (29 września). Armia francuska wkroczyła do Serbii i było tylko kwestią czasu, gdy stanie u południowych granic Węgier. Żołnierze węgierscy stacjonujący na froncie włoskim zaczęli wypowiadać posłuszeństwo dowództwu, żądając natychmiastowego przerzucenia ich do kraju, by bronić go przed Francuzami. Tymczasem 14 października Edvard Beneš poinformował państwa Ententy o powołaniu czechosłowackiego rządu tymczasowego (powołany został już 26 września) ${ }^{56}$. Tego samego dnia (14 października) w Czechach wybuchł strajk generalny zorganizowany przez Radę Socjalistyczną, którą tworzyli reprezentanci socjaldemokratów i narodowych socjalistów. W jego trakcie socjaliści ogłosili powstanie niepodległego państwa czechosłowackiego. Tylko za sprawą biernej postawy Komitetu Narodowego, która uznała to działanie za przedwczesne, proklamacja pozostała na papierze ${ }^{57}$.

Cesarz Karol jeszcze latem poinformował Wilhelma II, że Austro-Węgry nie są w stanie przeżyć kolejnej zimy i jeśli Niemcy nie zdecydują się na pokój, Wiedeń podpisze go sam. Na początku września obaj monarchowie wystosowali notę do prezydenta Wilsona oferującą podjęcie rozmów pokojowych na warunkach jego 14-punktowego programu pokojowego z 8 I 1918 r. ${ }^{58}$ Czekając na odpowiedź z Waszyngtonu Karol I, po uzgodnieniach z premierem Maxem Hussarkiem (1865-1935) i za zgodą Rady Koronnej, wydał 16 października manifest zapowiadający przekształcenie Przedlitawi w państwo federacyjne złożone z czterech części:

\footnotetext{
55 E. Beneš, Světová válka, II., s. 230, 283, s. 313.

56 Tamże, s. 363-365.

57 Z. Kárník, Socialisté na rozcestí, s. 293-294.

58 Punkt 10 mówił o autonomii narodów Austro-Węgier. Patrz: H. Seton-Watson, C. SetonWatson, The Making of a New Europe. R. W. Seton-Watson and the Last Years of Austria-Hungary, London 1981, s. 243.
} 
czeskiej, niemieckiej, polskiej i jugosłowiańskiej ${ }^{59}$. Projekt ten nie miał już jednak szans na realizację. Premier rządu węgierskiego Sándor Wekerle (1848-1912) już podczas posiedzenia Rady Koronnej zapowiedział, że nie poprze go, jeśli nie otrzyma gwarancji integralności terytorialnej Węgier. Dla Czechów nie do przyjęcia była koncepcja podziału ziem czeskich na podstawie kryterium narodowościowego. Pozytywnym efektem manifestu był jednak fakt, że poszczególne rady i komitety narodowe mogły zacząć przejmować władzę pod pretekstem realizacji zawartych w nim zapowiedzi. Tak postąpił i czeski Komitet Narodowy. Wydanie manifestu zaniepokoiło Masaryka, wciąż przebywającego w Ameryce. 18 października wydał w imieniu rządu tymczasowego deklarację o powstaniu niepodległej Czechosłowacji ${ }^{60}$. W ślad za tym prezydent Wilson, za pośrednictwem Departamentu Stanu oświadczył, że odrzuca propozycję, by rozmowy pokojowe prowadzone były na podstawie jego własnego programu i zaleca rządowi Austro-Węgier, żeby podjęła negocjacje z przedstawicielami poszczególnych narodów, jeśli tylko są gotowe pozostać częścią monarchii ${ }^{61}$.

Na korzyść cesarza Karola niewątpliwie przemawia fakt, że gdy tylko zdał sobie sprawę z nieuniknionego rozpadu monarchii, nie zdecydował się bronić jej za wszelką cenę, a jedynie zapewnić spokojny przebieg wydarzeń. Paradoksalnie jako pierwsi ze swoimi żądaniami wystąpili austriaccy Niemcy, chcący zjednoczenia z Cesarstwem Niemieckim. 22 października na dworcu w Döbling pod Wiedniem cesarz spotkał się w przywódcą narodowych socjalistów Václavem Klofačem, informując za jego pośrednictwem czeskich polityków, że liczy się z powstaniem niepodległego państwa czeskiego i nie zamierza się temu sprzeciwiać. Dał wyraźnie do zrozumienia, że jeśli wszystko będzie przebiegać spokojnie, armia nie będzie interweniować. Cesarz zgodził się, by delegacja środowisk związanych z „Mafią” wyjechała do Szwajcarii, by tam spokojnie omówić plan budowy nowego państwa ${ }^{62}$.

W niedzielę 27 X 1918 r. ostatni austro-węgierski minister spraw zagranicznych Gyula Andrássy młodszy (1860-1929) po uzgodnieniu z cesarzem wystosował za pośrednictwem Szwecji notę do prezydenta Wilsona, w której informował, że Austro-Węgry przyjmują wszelkie warunki konieczne do podjęcia rozmów pokojowych. Jednocześnie zerwano sojusz z Niemcami, które zamierzały kontynuować wojnę.

\footnotetext{
59 J. Galandauer, Karel I., s. 229-230.

60 E. Beneš, Světová válka, III., dok. 177, s. 472-477.

61 F. Soukup, 28. ř́jen, II., s. 979-980.

62 Tamże, s. 965-966.
} 
Gdy poinformowały o tym poniedziałkowe gazety, prażanie byli przekonani, że Austro-Węgry skapitulowały. W całym mieście zaczęto organizować uliczne demonstracje. W ich trakcie zrywano z budynków austriackie symbole państwowe i żądano oficjalnego ogłoszenia niepodległości. Oczekiwaną proklamację Komitet Narodowy wydał jeszcze tego samego dnia po południu ${ }^{63}$. Władzy Rady podporządkowali się urzędnicy namiestnika cesarskiego i dyrekcji policji. W trakcie kolejnych dwóch dni Rada przejęła władzę także w innych czeskich miastach, podporządkowała się jej większość czeskich starostów, żandarmów i policjantów. Nowej władzy nie uznali za to niemieckojęzyczni mieszkańcy Czech, którzy dzień po proklamowaniu niepodległej Czechosłowacji, 29 października, ogłosili powstanie prowincji Niemieckie Czechy (Deutschböhmen) ze stolicą w Libercu i zadeklarowali swoją wierność wobec Austrii, która 4 listopada zdecydowała się podpisać rozejm. Czescy Niemcy nie kryli, że ich celem jest przyłączenie tak Niemieckich Czech jak i całej Austrii, której terytorium znacznie się zmniejszyło wraz z ogłaszaniem niepodległości przez kolejne narody, do Niemiec $^{64} .30$ października w Turčianskim sv. Martinie zebrało się Zgromadzenie Założycielskie Słowackiej Rady Narodowej, które ogłosiło oderwanie Słowacji od Węgier i jej połączenie z ziemiami czeskimi ${ }^{65}$.

Czechosłowacja powstała z woli obu narodów, jednak ich stosunek do wspólnego państwa był odmienny. Stało się to, czego tak obawiała się Liga Słowacka w Ameryce. Czesi uważali Czechosłowację za czeskie państwo poszerzone na wschodzie o ziemie słowackie, w pełni się z nim identyfikując. Jako państwo czeskie uznawano Czechosłowację także za granicą, gdzie określenia „czeski” i „czechosłowacki” stosowano jak synonimy (mówiło się np. „rząd czeski”, „korona czeska”, a i samą Czechosłowację nieraz nazywano Czechami). Z kolei większość Słowaków postrzegała wspólne państwo inaczej. Nie chciała Czechosłowacji lecz Czecho-Słowacji, dwóch oddzielnych państw tworzących wspólnotę. Z kształtem Czechosłowacji nie zgadzały się też mniejszości narodowe, mające własne państwa tuż za granicami. Doszło do

63 Proklamację niepodległości z 28 X 1918 r. podpisało pięciu polityków: w imieniu socjaldemokratów František Soukup, w imieniu narodowych socjalistów Jiří Stříbrný (1880-1955), w imieniu agrarystów Antonín Švehla (1873-1933), a w imieniu demokratów państwowoprawnych Alois Rašín. Piątym sygnatariuszem był Vavro Šrobár, który przyjechał tego dnia do Pragi z pełnomocnictwem słowackich partii politycznych. Nazwano ich później „mężami 28 października”.

64 M. Melanová, Vznik Československa: Deustchböhmen a Liberec 1918-1919, Liberec 2019, s. 19-44.

65 DSNIŠ, I., dok. 161, s. 513-514. 
paradoksalnej sytuacji. Austro-Węgry, nazywane „więzieniem narodów”66 co szczególnie w przypadku Przedlitawi nie było uprawnionym określeniem, rozpadły się, nie umiejąc rozwiązać problemów narodowościowych. Stało się tak nie z braku dobrej woli lecz dlatego, że po prostu nie dało się ich rozwiązać tak, by wszyscy byli zadowoleni. Z wyjątkiem niemieckiej Republiki Austrii, proklamowanej po abdykacji cesarza Karola I 11 XI 1918 r., i szczątkowego państwa węgierskiego, które odłączyło się od monarchii habsburskiej jeszcze 31 października, wszystkie państwa, które powstały na gruzach Austro-Węgier: Czechosłowacja, Królestwo Serbów, Chorwatów i Słoweńców (późniejsza Jugosławia) i Polska, były tak samo wielonarodowościowe. Można wręcz powiedzieć, że pod tym względem stanowiły pomniejszoną kopię monarchii austro-węgierskiej. Wszystkie te państwa musiały wkrótce stawić czoła takim samym problemom jak upadła monarchia, a doszło do nich jeszcze wiele innych.

Ttumaczenie z języka czeskiego: Marcin Czyżniewski

Nadesłany: 29 IX 2019

Nadesłany po poprawkach recenzyjnych: 12 XI 2019

Zaakceptowany: 10 XII 2019

Prof. PhDr. Jan Rychlík, DrSc.

ORCID 0000-0002-0636-1005

Ústav českých dějin

Filozofická fakulta Univerzita Karlova

Náměstí Jana Palacha 2

11638 Praha 1

email: rychlik@email.cz

\section{Czechs and Slovaks on the road to an independent state (1914-1918)}

Before 1914, Czechs wanted to implement their national program of transforming the Austrian-Hungarian dualism into "trialism". This program could not have been followed because it was aimed against Bohemian, Moravian and Silesian Germans who wanted to establish their own German-speaking province (Deutschböhmen) in the Bohemian Crown. Slovaks made an attempt to federalize Hungary and to establish an autonomous Slovak

66 „Więzieniem narodów” określano też ironicznie zamek Špilberk, w którym rzeczywiście więziono rewolucjonistów wszystkich narodowości monarchii austro-węgierskiej. 
territory. This also was impossible because the ultimate aim of Hungarians was to create a single-language Magyar nation state. At the beginning of WWI, most Czech and Slovak political parties remained loyal to Austria-Hungary. Only a small group of politicians with Thomas Garrigue Masaryk in the lead, decided that the time was ripe for a completely new policy: supporting the Entante powers (France, Great Britain, Russia, later also Italy, and the US), military destruction of Austria-Hungary, and - after its defeat - proclamation of an independent Czecho-Slovak state. Thomas Garrigue Masaryk, Edvard Beneš and Milan Rastislav Štefánik established Czechoslovak National Council (CzNC) in Paris in 1916 with the aim of persisting the Entante powers to accept the plan of dismantling Austria-Hungary. However, this did not occur until 1918 when gradually France, Great Britain and the US recognized the $\mathrm{CzNC}$ as a provisional government of the future Czechoslovakia. The independence of Czechoslovakia was formally proclaimed in Prague on 28 October 1918.

Translated by: Ewa Dratwa 